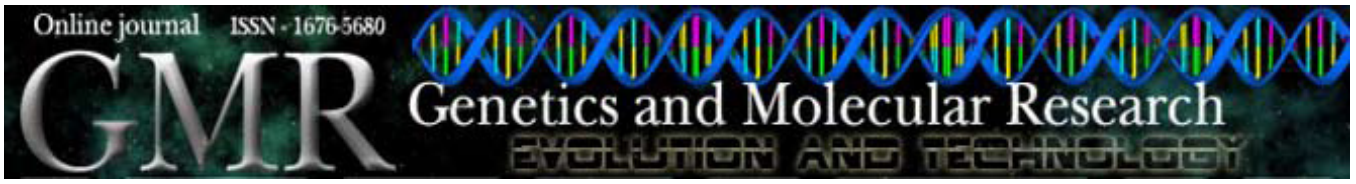

\title{
TP53 gene expression, codon 72 polymorphism and human papillomavirus DNA associated with pterygium
}

\author{
F.W. Rodrigues ${ }^{1,2 *}$, J.T. Arruda ${ }^{3 *}$, R.E. Silva $a^{1,2}$ and K.K.V.O. Moura ${ }^{2,3}$ \\ ${ }^{1}$ Fundação Banco de Olhos de Goiás, Goiânia, GO, Brasil \\ ${ }^{2}$ Programa de Pós-Graduação Stricto Sensu, Mestrado em Genética, \\ Goiânia, GO, Brasil \\ ${ }^{3}$ Universidade Católica de Goiás, Departamento de Biologia, \\ Núcleo de Pesquisas Replicon, Goiânia, GO, Brasil \\ *These authors contributed equally to this study. \\ Corresponding author: K.K.V.O. Moura \\ E-mail: katiakarinav@yahoo.com.br; jalsitacon@yahoo.com.br
}

Genet. Mol. Res. 7 (4): 1251-1258 (2008)

Received September 16, 2008

Accepted October 1, 2008

Published November 11, 2008

\begin{abstract}
Pterygium is a disease of unknown origin and pathogenesis that can be vision threatening. Several researchers believe that pterygium is UV-related and that abnormal expression of p53 protein and infection with human papillomavirus (HPV) are risk factors for pterygium, but their experiments have been inconclusive. We investigated its relation with $\mathrm{p} 53$ protein expression, $\mathrm{p} 53$ gene codon 72 polymorphism and infection with HPV DNA. Pterygial samples were obtained from 36 patients; 21 normal conjunctival samples were used as controls. Expression of p53 protein was studied by immunohistochemistry, using the antibody DO-7. Analysis for the $\mathrm{p} 53$ genotype was made by polymerase chain reaction, using specific primers for the arginine and proline alleles, and an analysis for HPV was made of the pterygium patients and control group. Fourteen of the 36 pterygial specimens were positive for abnormal p53 expression. Thirty-one of the patients were heterozygotic and three were homozygotic for the proline allele; two were homozygotic for the arginine allele; in the control group 12 of 21 were heterozy-
\end{abstract}


gotic and seven of these 21 were homozygotic for the proline allele; two were homozygotic for the arginine allele. Twenty-one of the pterygium patients were positive for HPV; HPV type 1 was found in nine of these, type 2 in seven and both types in five. Only two of the 21 controls had HPV; both had type 16. We suggest that abnormal expression of $\mathrm{p} 53$, p53 codon 72 polymorphisms and HPV DNA are required co-factors for the development of pterygium.

Key words: Pterygia; Brazilian; Ophthalmology

\section{INTRODUCTION}

Pterygium is a fleshy, triangular or wing-shaped surface ocular lesion that begins growing from limbal epithelium and invades the cornea centripetally, followed by degenerative and hyperplastic changes in the conjunctival epithelium, as well as proliferative, inflammatory features and a rich vasculature. The histological feature of pterygium overgrowth is excessive fibrovascular proliferation, basement membrane (Bowman's membrane) degradation, and the superficial corneal stroma is invaded by the fibrovascular tissue (Hirst, 2003). Indications for surgical excision include impending or manifest visual loss due to involvement of the central cornea, irregular astigmatism attributable to central corneal encroachment, restriction of ocular motility, and atypical appearance, leading to concerns of squamous neoplasia (van Setten et al., 2003).

Risk factors for the development of pterygium have been evaluated in different parts of the world and have provided evidence that a genetic component may be involved in the pathology of pterygium (Detorakis et al., 2000), while anti-apoptotic mechanisms (Tan et al., 2000; Sakoonwatanyoo et al., 2004), cytokines (Di Girolamo et al., 2002), growth factors (Kria et al., 1998; Liu et al., 2002; Nolan et al., 2003; van Setten et al., 2003), angiogenic factors (Marcovich et al., 2002; Ribatti et al., 2007), extracellular matrix remodeling (Di Girolamo et al., 2000), immunologic mechanisms (Perra et al., 2002), and viral infections (Detorakis et al., 2000, 2001; Gallagher et al., 2001; Piras et al., 2003) have all been implicated in its pathogenesis.

Epidemiological studies indicate that chronic exposure to sunlight, including most probably ultraviolet B (UV-B) irradiation, is an important factor in the development of pterygium (Cullen, 2002; Kau et al., 2006). It is known that UV irradiation has a carcinogenic effect, resulting in DNA damage with loss of normal growth control (Ichihashi et al., 2003; Hussein, 2005).

Abnormal levels of $\mathrm{p} 53$ protein have been found in the epithelium; many researchers feel that pterygium is a UV-related, uncontrolled, cell proliferation consistent with that of a tumor (Ueda et al., 2001; Weinstein et al., 2002). The p53 tumor suppressor gene is one of the most commonly mutated genes observed in human tumors and has been noted in more than $50 \%$ of all human cancers (Tsai et al., 2004). In normal unstressed cells, p53 is a short-lived protein, which is maintained at low, often undetectable levels in the cell, but mutations in p53 lead to increased stability of its protein, in the cell, which can be detected by antibodies to several epitopes of p53. Nearly all reported studies about the p53 gene in pterygium have used immunohistochemical (IHC) staining. The reported 
prevalence of $\mathrm{p} 53$-positive staining or presumed p53 gene mutation ranges widely, from 7.9 to $100 \%$ (Onur et al., 1998; Dushku et al., 1999; Tan et al., 2000; Chowers et al., 2001; Weinstein et al., 2002).

Though many researchers think that pterygium is a UV-related uncontrolled cell proliferation or tumor, whether there is a $\mathrm{p} 53$ genetic mutation in pterygium is controversial (Tsai et al., 2005a). Ultraviolet radiation has been reported to be associated with pterygium formation; however, the mechanism whereby UV induces uncontrolled proliferation in pterygial cells and the cause of p53 mutation are still unclear.

We examined the expression of p53 protein by IHC techniques, p53 gene codon 72 polymorphisms and detection of HPV DNA in pterygium.

\section{MATERIAL AND METHODS}

\section{Tissues}

Pterygial samples were obtained from 36 patients submitted to excision of pterygia at the Fundação Banco de Olhos de Goiás during July 2006. Fifteen men and 21 women were enrolled in the study, with ages ranging from 15 to 70 years. Twenty-one normal conjunctival samples from age- and sex-matched controls were included for comparison. All biopsy material was fixed in $10 \%$ buffered formalin, $\mathrm{pH} 7.3$, and was paraffin embedded. Sections $(5 \mu \mathrm{m})$ were cut in a microtome by methods that reduce the risk of cross-contamination, were mounted on glass slides, and dried overnight at $37^{\circ} \mathrm{C}$ for IHC and DNA analysis. Twenty-one sclera tissues without pterygium were included as the control group. All subjects agreed to be included in our research project after the nature of the study had been explained and they had been interviewed by an ophthalmologist. Patients did not receive any medication prior to surgery, except for a topical anesthetic, and no drugs or chemical agents were used during intervention. The study protocol was approved by the local Research Ethics Committee, and informed consent was obtained from all volunteers in this study; complete information on patients was available in all cases.

\section{Immunohistochemistry analysis of $\mathbf{p 5 3}$ protein expression}

IHC detection of $\mathrm{p} 53$ was made using streptavidin-biotin alkaline phosphatase and incubation with the anti-p53 antibody (clone DO-7, Dako, Denmark). Results were evaluated and scored for the percentage of positive nuclei. The cutoff level for IHC analysis was set at $10 \%$, meaning that those samples with more than $10 \%$ of cells stained were considered to be positive.

\section{DNA isolation}

The genomic DNA was extracted from pterygium tissues deparaffinized from five serial sections from each case; these were collected on a single cap and digested with proteinase $\mathrm{K}$ solution $(200 \mu \mathrm{g} / \mathrm{mL})$ and incubated at $55^{\circ} \mathrm{C}$ for $24 \mathrm{~h}$. The samples were heated for $10 \mathrm{~min}$ at $95^{\circ} \mathrm{C}$ to denature the proteinase $\mathrm{K}$, following the instructions of the PureGene $^{\mathrm{TM}}$ (Quiagen Biotech, USA). 


\section{Analysis for p53 gene codon 72 polymorphism}

For p53, the primer Pro-72 was designed for p53 codon 72 in the proline form and Arg-72 for the arginine form, according to the procedure described by Storey et al. (1998). The polymerase chain reaction (PCR) products were loaded on a $2 \%$ agarose gel containing ethidium bromide for electrophoresis.

\section{Analysis for human papillomavirus}

The PCR with GP5/GP6 was performed as described previously (Husnjak et al., 2000). The primers amplify a 140-150-bp fragment (depending on human papillomavirus (HPV) type) from the L1 gene. The PCR product was analyzed on a 3\% agarose gel stained with ethidium bromide. DNA samples extracted from cell cultures infected with HPV were used as a positive control. The positive samples were HPV typed with specific primers (Table 1).

\begin{tabular}{|c|c|}
\hline Primer & Sequence $5^{\prime} \rightarrow 3^{\prime}$ \\
\hline \multirow[t]{2}{*}{ TP53 ARG } & F-5' CTGGTGCAGGGGCCACGC -3' \\
\hline & R-5' CGTGCAAGTCACAGACTT -3' \\
\hline \multirow[t]{2}{*}{ TP53 PRO } & F-5' GCCAGAGGCTGCTCCCCC -3' \\
\hline & R-5' ATCTACAGTCCCCCTTGCCG -3' \\
\hline GP5+ & F-5' TTTGTTACTGTGGTAGATACTAC -3' \\
\hline GP6+ & R-5' GAAAAATAAACTGTAAATCATATTC -3' \\
\hline \multirow[t]{2}{*}{ HPV-1 } & F-5' TTTGGTGTTTGGATGCTGTC -3' \\
\hline & R-5' TGCACTCTTTCTCCGTTTGA -3' \\
\hline \multirow[t]{2}{*}{ HPV-2 } & F-5' GCGACGATGAGTTTGGATTT -3' \\
\hline & R-5' CAAGTGAAAGTTGGCTGCAA -3' \\
\hline \multirow[t]{2}{*}{ HPV-6 } & F-5' CACGTCTGCAACGACCATAG -3' \\
\hline & R-5'CCATGAAATTCTAGGCAGCA -3' \\
\hline \multirow[t]{2}{*}{ HPV-11 } & F-5' CGCAGAGATATATGCATATGC -3' \\
\hline & R-5' AGTTCTAAGCAACAGGCACAC -3' \\
\hline \multirow[t]{2}{*}{ HPV-16 } & F-5' TCAAAAGCCACTGTGTCCTGA -3' \\
\hline & R-5' CGTGTTCTTGATGATCTGCAA -3' \\
\hline \multirow[t]{2}{*}{ HPV-18 } & F-5' CCGAGCACGACAGGAACGACT -3' \\
\hline & R-5' TCGTTTTCTTCCTCTGAGTCGCTT -3' \\
\hline \multirow[t]{2}{*}{ HPV-33 } & F-5' AACGCCATGAGAGGACACAAG -3' \\
\hline & R-5'ACACATAAACGAACTGTGGTG -3' \\
\hline \multirow[t]{2}{*}{ HPV-35 } & F-5' CCCGAGGCAACTGACCTATA -3' \\
\hline & R-5' GGGGCACACTATTCCAAATG -3' \\
\hline \multirow[t]{2}{*}{ HPV-45 } & F-5’ ACCAGATTTGTGCACAGAAT -3' \\
\hline & R-5' TTTTTTCCAGTGTCTCTCCA -3' \\
\hline \multirow[t]{2}{*}{ HPV-58 } & F-5' GGACATTGCATGATTTGTGT -3’ \\
\hline & R-5' TTTCTTGTGGACACAATGGT -3' \\
\hline
\end{tabular}

\section{RESULTS}

Positive staining for $\mathrm{p} 53$ was detected in 24 of the 36 pterygial specimens and 12 were considered to be p53 staining negative (no immunoreactive cells visible). Twenty-three had $<50 \%$ and 13 had $>50 \%$ immunoreactive cells (Figure 1 ). The cutoff $\geq 10 \%$ of immunoreactive 
cells was found in 14/36 of the patients. P53 staining was limited to the nuclei of cells in the epithelial layer. No substantial staining was visible in the subepithelial fibrovascular layers. None of the specimens displayed immunoreactive staining.

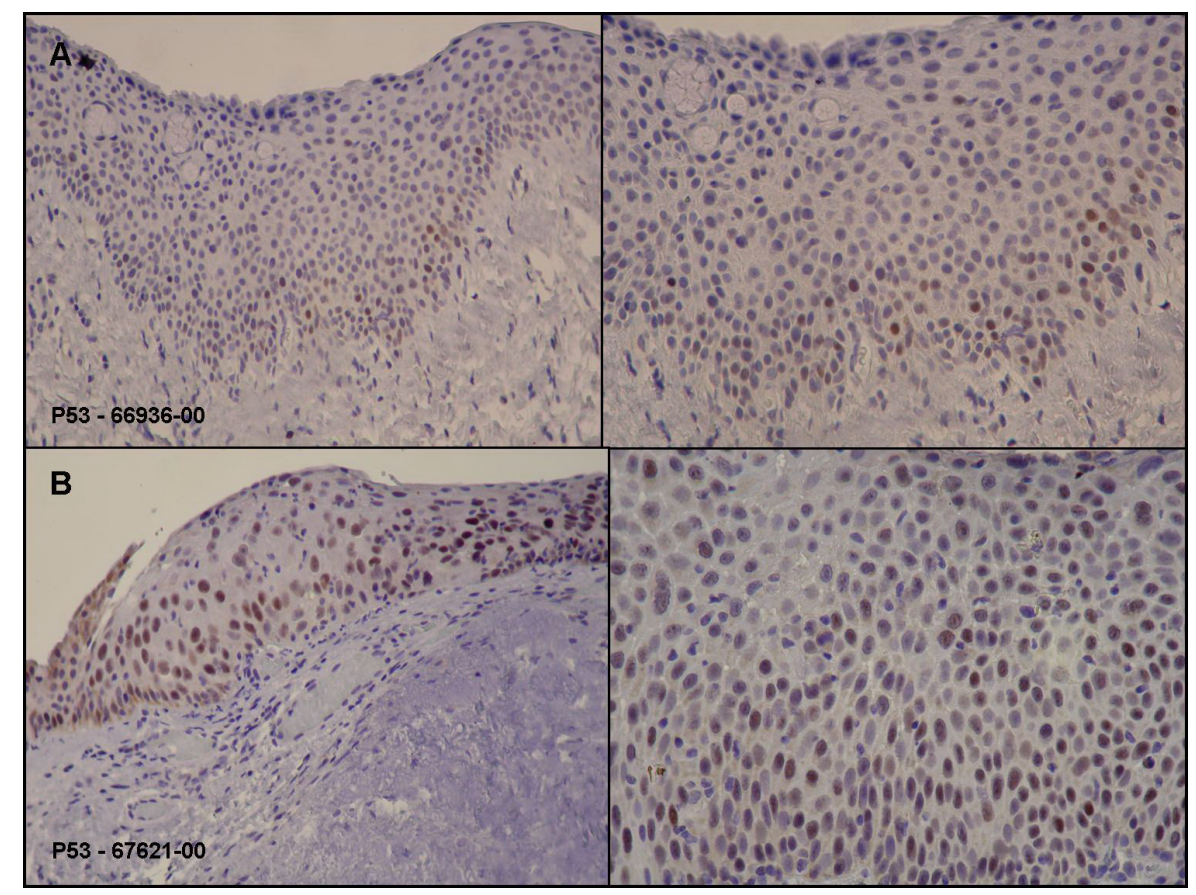

Figure 1. Immunohistochemical staining with monoclonal antibody DO-7 of a pterygium section showing positive staining (brown nuclei) for $\mathrm{p} 53$. A. $10 \%$ positive nuclei $\mathrm{p} 53$ cells. B. $90 \%$ positive nuclei p 53 cells.

The frequency of the p53 codon 72 polymorphisms did not differ significantly between the pterygium group and the control group (Table 2). Twenty-one of the pterygia were also positive for HPV DNA, as were two samples from the control group. HPV type 1 was found in $9 / 21$, type 2 in $7 / 21$ and both types simultaneously in $5 / 21$ of the control group; type 16 was found in two specimens.

Table 2. Distribution of p53 codon 72 polymorphism and allelic frequencies in the pterygium and control groups.

\begin{tabular}{lcr}
\hline Genotype & $\begin{array}{c}\text { Pterygium } \\
(\mathrm{N}=36)\end{array}$ & $\begin{array}{c}\text { Control } \\
(\mathrm{N}=21)\end{array}$ \\
\hline Arg/Arg & 2 & 2 \\
Arg/Pro & 31 & 12 \\
Pro/Pro & 3 & 7 \\
\hline
\end{tabular}




\section{DISCUSSION}

We and other researchers (Dushku and Reid, 1997; Dushku et al., 1999; Tan et al., 1997, 2000; Chowers et al., 2001; Ueda et al., 2001; Weinstein et al., 2002; Perra et al, 2006; Schneider et al, 2006) found pterygium cells to be p53 positive by IHC. The antip53 antibody and cutoff level (10\% cell staining) that we used was the same as that used by Weinstein et al. (2002) and by Tsai et al. (2005b); however, the previously reported frequencies of 53.8 and $22.8 \%$, respectively, differed from our finding of $24 / 36$. The frequency of p53 mutations in cancer patients can vary among different races (Beroud and Soussi, 2003), and our country is quite miscegenated. Ueda et al. (2001) demonstrated that the incidence of immunoreactivity for $\mathrm{p} 53$ is affected by race differences in the development of pterygium as well as by environmental factors. This accumulated p53 protein is apparently mostly inactive, at least in terms of how it affects apoptosis. Weinstein et al. (2002) suggest that the p53 mutation in pterygium is provoked by ultraviolet radiation or it may be hereditary. Detorakis et al. (2000) proposed two models for DNA abnormalities in pterygium. The first involved ultraviolet radiation or inherited traits, and the second involved viral infection or sunlight.

We analyzed the p53 codon 72 polymorphism with a single nucleotide polymorphism marker. Single nucleotide polymorphism markers have provided a new method for identification of complex gene-associated diseases, such as tumors (Hussein, 2005) and p53 codon 72 polymorphisms, the most important markers for tumor susceptibility. We observed that $31 / 36$ of our samples were heterozygotic, three were homozygotic for the proline allele and two were homozygotic for the arginine allele in the pterygium group, while in the control group 12/21 were heterozygotic, seven were homozygotic for the proline allele and two were homozygotic for the arginine allele. However, there were no significant differences between the pterygium and the control groups.

The p53 gene is a tumor suppressor gene, and polymorphisms of p53 codon 72 have been found to be associated with many types of tumors (Storey et al., 1998). In normal unstressed cells, the p53 protein has a short half-life and is maintained at low, often undetectable, levels. Mutations in the p53 gene are believed to lead to an increased stability of its protein product, allowing a more pronounced IHC detection. UV radiation can cause mutation in genes such as p53. Because of the abnormal expression of the p53 gene in pterygium epithelium, and evidence that hereditary factors have a role in the development of pterygium, it is logical to suspect a correlation between pterygium formation and p53 polymorphisms (Reisman et al., 2004).

We confirm that HPV DNA can be detected in the pterygium and conjunctival tissues. We found HPV DNA types 1 and 2 in the pterygial group and 16 in the control group, which may be involved in the pathogenesis of these lesions (Dolmetsch et al., 1996). Conjunctival carcinoma has been associated with concomitant viral infection, with HPV being implicated in a large proportion of cases (Varinli et al., 1994; Gallagher et al., 2001). Conjunctival papillomas tend to recur after excision; this recurrence may reflect persistent viral infection. Pterygium also tends to recur after excision, with recurrence rates of up to $46 \%$ after a seven-year follow-up period (Tsai et al., 2005c). If HPV is involved in the pathogenesis of these lesions, persistent conjunctival HPV infection may also lead to pterygium recurrence and consequently, recurrent pterygium should be examined for HPV 
DNA. Moreover, if HPV has a role in pterygium recurrence, antiviral treatment might be used in the future to prevent recurrence.

In conclusion, although the pathogenesis of pterygia is still unclear, the concomitant presence of abnormal expression of $\mathrm{p} 53$ protein, codon 72 polymorphism and HPV DNA supports the hypothesis that not only UV radiation is required. This may also mean that different lifestyles, environmental conditions and genetic factors also contribute to the development of pterygium. However, further more extensive studies are necessary to further test this hypothesis and to elucidate pterygium pathogenesis, with larger samples from different regions.

\section{ACKNOWLEDGMENTS}

Research supported by Universidade Católica de Goiás, Goiânia, GO, Brazil (UCG/PROPE/MGene). We are grateful to Fundação Banco de Olhos de Goiás. J.T. Arruda was the recipient of a fellowship from the Conselho Nacional de Desenvolvimento Científico e Tecnológico (CNPq).

\section{REFERENCES}

Beroud C and Soussi T (2003). The UMD-p53 database: new mutations and analysis tools. Hum. Mutat. 21: 176-181.

Chowers I, Pe'er J, Zamir E, Livni N, et al. (2001). Proliferative activity and p53 expression in primary and recurrent pterygia. Ophthalmology 108: 985-988.

Cullen AP (2002). Photokeratitis and other phototoxic effects on the cornea and conjunctiva. Int. J. Toxicol. 21: 455-464.

Detorakis ET, Drakonaki EE and Spandidos DA (2000). Molecular genetic alterations and viral presence in ophthalmic pterygium. Int. J. Mol. Med. 6: 35-41.

Detorakis ET, Sourvinos G and Spandidos DA (2001). Detection of herpes simplex virus and human papilloma virus in ophthalmic pterygium. Cornea 20: 164-167.

Di Girolamo N, McCluskey P, Lloyd A, Coroneo MT, et al. (2000). Expression of MMPs and TIMPs in human pterygia and cultured pterygium epithelial cells. Invest. Ophthalmol. Vis. Sci. 41: 671-679.

Di Girolamo N, Kumar RK, Coroneo MT and Wakefield D (2002). UVB-mediated induction of interleukin-6 and -8 in pterygia and cultured human pterygium epithelial cells. Invest. Ophthalmol. Vis. Sci. 43: 3430-3437.

Dolmetsch AM, Alcocer CE, Scull JJ, Martins MC, et al. (1996). The presence of human papillomavirus in pterygia. Invest. Ophthalmol. Vis. Sci. 37: S43.

Dushku N and Reid TW (1997). P53 expression in altered limbal basal cells of pingueculae, pterygia, and limbal tumors. Curr. Eye Res. 16: 1179-1192.

Dushku N, Hatcher SL, Albert DM and Reid TW (1999). p53 expression and relation to human papillomavirus infection in pingueculae, pterygia, and limbal tumors. Arch. Ophthalmol. 117: 1593-1599.

Gallagher MJ, Giannoudis A, Herrington CS and Hiscott P (2001). Human papillomavirus in pterygium. Is the virus a risk factor? Br. J. Ophthalmol. 85: 782-784.

Hirst LW (2003). The treatment of pterygium. Surv. Ophthalmol. 48: 145-180.

Husnjak K, Grce M, Magdic L and Pavelic K (2000). Comparison of five different polymerase chain reaction methods for detection of human papillomavirus in cervical cell specimens. J. Virol. Methods 88: 125-134.

Hussein MR (2005). Ultraviolet radiation and skin cancer: molecular mechanisms. J. Cutan. Pathol. 32: 191-205.

Ichihashi M, Ueda M, Budiyanto A, Bito T, et al. (2003). UV-induced skin damage. Toxicology 189: 21-39.

Kau HC, Tsai CC, Lee CF, Kao SC, et al. (2006). Increased oxidative DNA damage, 8-hydroxydeoxy-guanosine, in human pterygium. Eye 20: 826-831.

Kria L, Ohira A and Amemiya T (1998). Growth factors in cultured pterygium fibroblasts: immunohistochemical and ELISA analysis. Graefes Arch. Clin. Exp. Ophthalmol. 236: 702-708.

Liu Z, Xie Y and Zhang M (2002). Overexpression of type I growth factor receptors in pterygium. Chin. Med. J. 115: 418-421.

Marcovich AL, Morad Y, Sandbank J, Huszar M, et al. (2002). Angiogenesis in pterygium: morphometric and immunohistochemical study. Curr. Eye Res. 25: 17-22. 
Nolan TM, DiGirolamo N, Sachdev NH, Hampartzoumian T, et al. (2003). The role of ultraviolet irradiation and heparinbinding epidermal growth factor-like growth factor in the pathogenesis of pterygium. Am. J. Pathol. 162: 567-574.

Onur C, Orhan D, Orhan M, Dizbay SS, et al. (1998). Expression of p53 protein in pterygium. Eur. J. Ophthalmol. 8: 157-161.

Perra MT, Maxia C, Zucca I, Piras F, et al. (2002). Immunohistochemical study of human pterygium. Histol. Histopathol. 17: $139-149$

Perra MT, Maxia C, Corbu A, Minerba L, et al. (2006). Oxidative stress in pterygium: relationship between p53 and 8-hydroxydeoxyguanosine. Mol. Vis. 12: 1136-1142.

Piras F, Moore PS, Ugalde J, Perra MT, et al. (2003). Detection of human papillomavirus DNA in pterygia from different geographical regions. Br. J. Ophthalmol. 87: 864-866.

Reisman D, McFadden JW and Lu G (2004). Loss of heterozygosity and p53 expression in pterygium. Cancer Lett. 206: 77-83.

Ribatti D, Nico B, Maxia C, Longo V, et al. (2007). Neovascularization and mast cells with tryptase activity increase simultaneously in human pterygium. J. Cell Mol. Med. 11: 585-589.

Sakoonwatanyoo P, Tan DT and Smith DR (2004). Expression of p63 in pterygium and normal conjunctiva. Cornea 23: 67-70.

Schneider BG, John-Aryankalayil M, Rowsey JJ, Dushku N, et al. (2006). Accumulation of p53 protein in pterygia is not accompanied by TP53 gene mutation. Exp. Eye Res. 82: 91-98.

Storey A, Thomas M, Kalita A, Harwood C, et al. (1998). Role of a p53 polymorphism in the development of human papillomavirus-associated cancer. Nature 393: 229-234.

Tan DT, Lim AS, Goh HS and Smith DR (1997). Abnormal expression of the p53 tumor suppressor gene in the conjunctiva of patients with pterygium. Am. J. Ophthalmol. 123: 404-405.

Tan DT, Tang WY, Liu YP, Goh HS, et al. (2000). Apoptosis and apoptosis related gene expression in normal conjunctiva and pterygium. Br. J. Ophthalmol. 84: 212-216.

Tsai YY, Tsai YY, Cheng YW, Lee H, et al. (2004). No association of p53 codon 72 and p21 codon 31 polymorphisms in Taiwan Chinese patients with pterygium. Br. J. Ophthalmol. 88: 975-976.

Tsai YY, Chang KC, Lin CL, Lee H, et al. (2005a). p53 Expression in pterygium by immunohistochemical analysis: a series report of 127 cases and review of the literature. Cornea 24: 583-586.

Tsai YY, Cheng YW, Lee H, Tsai FJ, et al. (2005b). P53 gene mutation spectrum and the relationship between gene mutation and protein levels in pterygium. Mol. Vis. 11: 50-55.

Tsai YY, Chang KC, Lee H, Cheng YW, et al. (2005c). Effect of p53 codon 72 polymorphism on p53 protein expression in pterygium. Clin. Exper. Ophthalmol. 33: 60-62.

Ueda Y, Kanazawa S, Kitaoka T, Dake Y, et al. (2001). Immunohistochemical study of p53, p21 and PCNA in pterygium. Acta Histochem. 103: 159-165.

van Setten G, Aspiotis M, Blalock TD, Grotendorst G, et al. (2003). Connective tissue growth factor in pterygium: simultaneous presence with vascular endothelial growth factor - possible contributing factor to conjunctival scarring. Graefes Arch. Clin. Exp. Ophthalmol. 241: 135-139.

Varinli S, Varinli I, Koksal EM and Doran F (1994). Human papillomavirus in pterygium. Cent. Afr. J. Med. 40: 24-26.

Weinstein O, Rosenthal G, Zirkin H, Monos T, et al. (2002). Overexpression of p53 tumor suppressor gene in pterygia. Eye 16: 619-621. 